\title{
Angiogenin and SDF-1 $\alpha$ serum concentration in patients with systemic sclerosis in relation to clinical status
}

\author{
Bożena Dziankowska-Bartkowiak, Zofia Gerlicz-Kowalczuk, Elżbieta Waszczykowska
}

Department of Immunodermatology, Medical University of Lodz, Poland

Submitted: 14 September 2009

Accepted: 12 December 2009

Arch Med Sci 2011; 7, 1: 92-96

DOI: 10.5114/aoms.2011.20610

Copyright @ 2011 Termedia \& Banach

\begin{abstract}
Introduction: Systemic sclerosis (SSc) is a connective tissue disorder characterized by tissue hypoxia due to vascular changes and excessive fibrosis of the skin and internal organs. Damage to blood vessels and endothelium, as well as imbalance of vascular homeostasis, impairment of angiogenesis and vasculogenesis are observed in the course of the disease. The aim of the study was to investigate the pro-angiogenic factors angiogenin and SDF-1 $\alpha$ in patients with SSc.

Material and methods: Serum samples were collected from 50 patients with dSSc (diffuse SSc) and ISSc (limited SSc) and from 38 patients used as a healthy control group. We explored: 1) how the serum concentrations of SDF-1 $\alpha$ and angiogenin differ in the investigated groups; 2) the correlation among chemokines in SSc and the duration of the disease, Raynaud's phenomenon, sclerosis of the skin and TSS (total skin score).

Results: Patients with SSc showed statistically significantly higher serum angiogenin concentration and there was no correlation between duration of the disease and Raynaud's phenomenon, skin sclerosis or TSS. There was also no difference or no correlation between serum level of SDF-1 $\alpha$ and the investigated groups.

Conclusions: The increase in angiogenin concentration in the serum in patients with SSc may confirm endothelial damage caused by hypoxia and reduced vascular perfusion due to the course of SSc without contributing to compensatory revascularization.
\end{abstract}

Key words: systemic sclerosis, angiogenesis, vasculogenesis, angiogenin, SDF-1 $\alpha$.

\section{Introduction}

Systemic sclerosis (SSc) is an autoimmune disease in which the following characteristics are observed: vascular changes, sclerosis of the skin and of internal organs. The spectrum of vascular abnormalities extends from sclerosis of the skin to fibrosis of all organs.

It was proven that tissue hypoxia aggravates with the course of the disease due to reduced blood flow and that it induces formation of new blood vessels from the already existing ones (angiogenesis) or from endothelial progenitor cells (EPC) from the bone marrow (vasculogenesis) that circulate in the blood. Survival of tissue destroyed by the vascular autoimmune process is strictly dependent on angiogenesis. There are many factors, such as: modelling the angiogenesis process and formation of new capillaries stimulated by hypoxia, the inflammatory process and proangiogenic factors, such as vascular endothelial growth factor (VEGF) [1].

\section{Corresponding author:}

Zofia Gerlicz-Kowalczuk, MD

Department of

Immunodermatology

Medical University of Lodz

Krzemieniecka 5

94-017 Łódź, Poland

E-mail:

zosia_gerlicz@yahoo.com 
The literature on the subject confirms that regeneration of impaired vessels in the process of autoaggression depends on angiogenesis and also on vasculogenesis [2].

In the course of systemic sclerosis, a decreased number of EPC was described, related to the clinical stage of the disease and found to be directly proportional to the course of the disease [2]. EPC are released by the bone marrow and may play a vital role in formation of new vessels. Stromal cell-derived factor-alpha 1 (SDF-1 $1 \alpha$ ) and VEGF mediate the endothelial progenitor cells' mobilization and differentiation and have a strong influence on regulation of chemotaxis of the CXCR4 (chemokine [C-X-C] receptor 4)-expressing cell population [3]. Interestingly, it was observed that SDF- $1 \alpha$ acts locally within the hypoxic environment and stimulates direct differentiation of the recruited bone marrow cells into endothelial cells $[4,5]$. Moreover, it was proved that SDF-1 and CXCR4 were up-regulated in the skin of patients with early (oedematous) SSC, both in the diffuse and limited cutaneous forms, and they progressively decreased with the duration of the disease [6].

Although the pathogenesis of SSc is not completely understood, it is known that both vasculogenesis and angiogenesis are impaired. Angiogenin is one of the most potent proangiogenic factors and regulates vessel growth and plays a vital role in the process of angiogenesis and cell proliferation. The protein, exerting its ribonucleic activity, stimulates basement membrane degradation, endothelial cell penetration, migration and formation of tubular vascular structures. However, the angiogenin receptor is not known yet [7-9].

The present study was designed to widen and deepen the problem of angiogenesis disturbing factors in SSc, which might contribute to a better understanding of vascular abnormalities. We hypothesized that the cause of vascular abnormalities in patients with SSc might be correlated with the serum concentration of angiogenin and SDF-1 $\alpha$, which may have a prognostic implication for the duration and severity of the disease.

\section{Material and methods}

Forty-five females and 5 males with SSc (41 ISSc, $9 \mathrm{dSSc}$ ) were recruited from the Department of Dermatology and Venereology, Medical University of Lodz. The onset of the disease ranged from 1 to 30 years ago (mean 9 years) and was defined as the time at which skin involvement occurred. The mean age was 53 years (range from 20 to 77 years). The medical history and clinical examination were taken and, if necessary, additional tests were performed (Table I). All patients met the American College of Rheumatology criteria for the classification of SSc [10]. The severity of the disease was assessed according to international guidelines [1]. We measured the TSS (total skin score) according to Kahaleh's score [12]. At the time of serum collection for testing, all patients with SSc were taking vasodilator drugs and corticosteroids ( 9 patients, 5 with dSSc), methotrexate ( 2 patients, 1 with dSSc) and cyclophosphamide (2 patients, 1 with dSSc).

Systemic sclerosis patients were compared with the control subjects of the same sex and similar age with no systemic diseases or medication. Blood samples from the patients and the control subjects were collected from 8:00 to 9:00 am after overnight fasting. All samples were collected into trisodiumcitrated tubes and sera of all subjects were extracted from the blood samples after centrifugation at $2800 \mathrm{~g}$ for $10 \mathrm{~min}$ and stored at $-20^{\circ} \mathrm{C}$ until use.

In our study we used the SDF-1 $\alpha$ Immunoassay (R\&D Systems, Abingdon, Oxon, UK) and Human Angiogenin Immunoassay (R\&D Systems, Abingdon, Oxon, UK) based on quantitative colorimetric sandwich ELISA tests, according to the manufacturer's instructions.

We investigated the levels of the angiogenin and SDF- $1 \alpha$ concentration in the serum and their correlation with the duration of Raynaud's phenomenon, skin sclerosis and TSS.

Statistical significance was analysed by nonparametric Mann-Whitney test, Student's t-test and Spearman's rank correlation test. $P$ values less than 0.05 were considered significant.

The study was approved by the Ethical Committee of the Medical University of Lodz.

Table I. Clinical characteristic of the patients

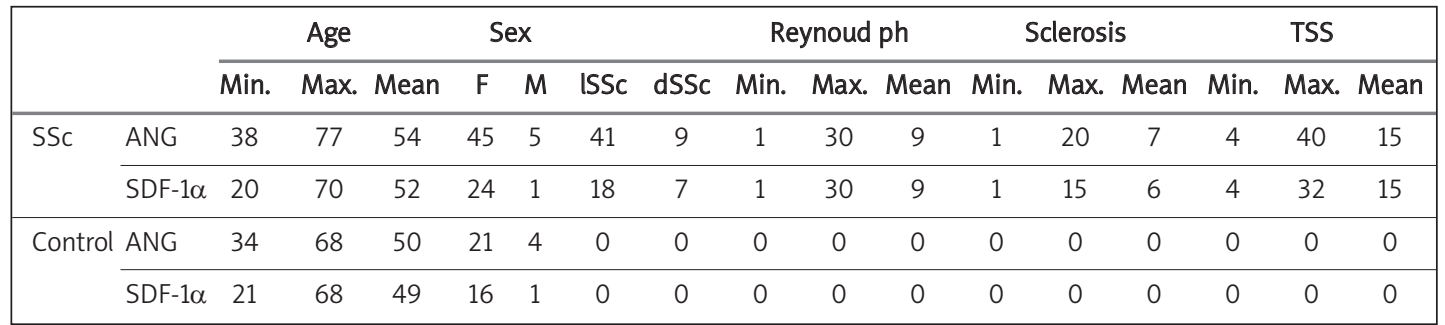

SSc - systemic sclerosis group, Control - control group, Reynould ph - Reynoud phenomenon duration, Sclerosis - sclerosis duration, TSS - Total Skin Score, F-female, $M$ - male, ISSC - limited SSc, dSSC-diffuse SSC 


\section{Results}

\section{Angiogenin}

In the investigated groups, higher concentrations of angiogenin in serum were found in SSc patients compared with the control subjects $(323.62 \mathrm{ng} / \mathrm{ml}$ vs. $255.31 \mathrm{ng} / \mathrm{ml}$; SD 90.39 vs. 39.48). The differences were statistically significant $(p=0.000082)$ (Table II).

There was no statistically significant difference between the patients with ISSc or dSSc taking or not taking immunosuppressive drugs (Tables III and IV).

The differences between serum concentration were not significant ( $p=0.974667)$ among the investigated groups - ISSC and dSSc. There was no correlation with the duration of Raynaud's phenomenon, skin sclerosis or TSS (Table V).

\section{SDF-1 $\alpha$}

There was no statistical difference in SDF-1 $\alpha$ serum concentration among the investigated groups (Table I).

There was no statistically significant difference between the patients with ISSC or dSSC and whether or not they took immunosuppressive drugs (Tables IV and V).

Although no statistically significant difference or correlation between serum concentration of SDF- $1 \alpha$ in the investigated parameters was found,

Table II. Serum concentration of angiogenin and SDF-1 $\alpha$ among SSc and control groups

\begin{tabular}{|c|c|c|c|c|c|c|c|c|c|c|c|c|}
\hline & \multicolumn{12}{|c|}{ Serum concentration [ng/ml] } \\
\hline & \multicolumn{5}{|c|}{ Angiogenin } & \multicolumn{7}{|c|}{ SDF-1 $\alpha$} \\
\hline & $n$ & Mean & Median & Min. & Max. & SD & $n$ & Mean & Median & Min. & Max. & $\mathrm{SD}$ \\
\hline ISSC & 35 & 322.48 & 329 & 28 & 551 & 96.05 & 17 & 2.594 & 2.601 & 2.015 & 3.675 & 0.411 \\
\hline $\mathrm{dSSC}$ & 10 & 327.60 & 310 & 255 & 495 & 71.22 & 7 & 2.653 & 2.597 & 2.223 & 3.473 & 0.418 \\
\hline Control & 25 & 255.31 & 249 & 177 & 336 & 39.48 & 16 & 2.746 & 2.662 & 2.084 & 3.954 & 0.442 \\
\hline
\end{tabular}

Angiogenin: ISSc-dSSc: $p=0.978219$; ISSc-Control: $p=0.000684$; dSSc-Control: $p=0.001230$

SDF-1 $\alpha$ : ISSc-dSSc: $p=0.974667$; ISSc-Control: $p=0.249042$; $d S S c$-Control: $p=0.639997$

$n$ - number of patients, SSC-systemic sclerosis group, Control - control group, SD - standard deviation

Table III. Comparison of serum concentration of angiogenin $(p=0.386449)$ and SDF-1 $\alpha(p=0.342789)$ between ISSc patients with/without immunosuppresive therapy

\begin{tabular}{|c|c|c|c|c|c|c|}
\hline \multicolumn{7}{|c|}{ Serum concentration $[\mathrm{ng} / \mathrm{ml}]$ of angiogenin and SDF-1 $\alpha$ between ISSc taking immunosuppressive drugs } \\
\hline & $n$ & Mean & Median & Min. & Max. & SD \\
\hline Angiogenin & 7 & 270.52 & 276.44 & 28.80 & 390.60 & 119.17 \\
\hline SDF-1 $\alpha$ & 5 & 2.67 & 2.72 & 2.26 & 2.90 & 0.26 \\
\hline \multicolumn{7}{|c|}{$\begin{array}{l}\text { Serum concentration }[\mathrm{ng} / \mathrm{ml}] \text { of angiogenin and SDF-1 } \alpha \text { between ISSc } \\
\text { and control groups not taking immunosuppressive drugs }\end{array}$} \\
\hline Angiogenin & 28 & 33.54 & 340.00 & 216.60 & 551.00 & 87.10 \\
\hline SDF-1 $\alpha$ & 12 & 2.56 & 2.44 & 2.01 & 3.67 & 0.44 \\
\hline
\end{tabular}

Table IV. Comparison of serum concentration of angiogenin $(p=0.522436)$ and SDF- $1 \alpha(p=0.288852)$ between dSSc patients with/without immunosuppresive therapy

\begin{tabular}{|c|c|c|c|c|c|c|}
\hline \multicolumn{7}{|c|}{ Serum concentration $[\mathrm{ng} / \mathrm{ml}]$ of angiogenin and SDF- $1 \alpha$ between dSSc taking immunosuppressive drugs } \\
\hline & $n$ & Mean & Median & Min. & Max. & SD \\
\hline Angiogenin & 6 & 325.10 & 30.60 & 255.80 & 495.00 & 88.27 \\
\hline SDF-1 $\alpha$ & 4 & 2.81 & 2.62 & 2.51 & 3.47 & 0.44 \\
\hline \multicolumn{7}{|c|}{$\begin{array}{l}\text { Serum concentration }[\mathrm{ng} / \mathrm{ml}] \text { of angiogenin and SDF-1 } \alpha \text { between dSSc } \\
\text { and control groups not taking immunosuppressive drugs }\end{array}$} \\
\hline Angiogenin & 4 & 331.35 & 321.40 & 287.60 & 395.00 & 46.90 \\
\hline SDF-1 $\alpha$ & 3 & 2.44 & 2.27 & 2.22 & 2.83 & 0.33 \\
\hline
\end{tabular}


we observed a tendency for a negative correlation between the serum level of SDF-1 $\alpha$ and the duration of Raynaud's phenomenon $(\rho=-0.270)$ and skin sclerosis $(\rho=-0.388$ ) (Table II). Similarly, we observed a tendency for a negative Spearman's correlation coefficient between SDF-1 $\alpha$ serum concentration and duration of the disease. However, these results were not statistically significant $(p>0.05)$.

\section{Discussion}

It seems that in the pathogenesis of systemic sclerosis neovasculogenesis, impairment is a vital element in the development of the disease. According to the literature on the subject, both an increase and a decrease in angio- and vasculogenesis may be a manifestation of the disease [13, 14].

This study confirms the hypothesis of deep impairment of angiogenesis in SSc. It is the first study demonstrating elevated angiogenin concentration in SSc patient serum compared with healthy subjects. Increased release of angiogenin may be indicative of compensatory ineffective angiogenesis in these patients which was not observed in revascularization of the healthy population.

It may also suggest that the process, which is dependent on this molecule, might not be impaired due to the course of SSc, but we hypothesized that the elevated level of angiogenin may occur due to the impairment of endothelial cell differentiation described by Cipriani [15], which showed decreased capacity of specific endothelial activities occurring in angiogenesis. A large decrease in the level of angiogenin reduces the capacity to induce tumour growth and angiogenesis, even in the presence of elevated bFGR (basic fibroblast growth factor) and VEGF [16].

Interestingly, the literature describes elevated angiogenin serum level in chronic heart failure [17], which is related to worsening of heart failure severity. Tello-Montoliu [18] described increased plasma angiogenin level in acute coronary syndromes with predictive adverse events during the follow-up and correlated this protease with the destabilization of atherosclerotic plaque.

In addition to defective angiogenesis, vasculogenesis is also impaired in SSc. Reduced numbers and functional defects of endothelial progenitor cells are observed despite increased endothelial cell activation markers $[19,20]$.

Considering the insufficient vasculogenesis in SSc patients, up-regulation in SDF-1 $\alpha$ level could be expected, which could have a positive effect on the described lower number of EPC in patients with systemic sclerosis $[2,15]$. SDF- $1 \alpha$ takes part in the promotion of recruitment, growth and survival of cells from the bone marrow stromal stem cells [21]. Their participation in tissue regeneration in ischaemic cardiomyopathy is well described.
Table V. Correlation among angiognenin and SDF-1 $\alpha$ serum concentration and the duration of Raynould phenomenon, skin sclerosis and TSS

\begin{tabular}{|lcccc|}
\hline & & Raynoud ph & Skin sclerosis & TSS \\
\hline Angiogenin & $\rho$ & 0.127 & 0.096 & 0.078 \\
\cline { 2 - 5 } & $p$ & $>0.05$ & $>0.05$ & $>0.05$ \\
\hline SDF-1 $\alpha$ & $\rho$ & -0.270 & -0.388 & 0.058 \\
\cline { 2 - 5 } & $p$ & $>0.05$ & $>0.05$ & $>0.05$ \\
\hline
\end{tabular}

Reynould ph-Reynoud phenomenon duration, skin sclerosis - skin sclerosis duration, TSS - Total Skin Score

$\rho$-Spearman's rank correlation coefficient, $p>0.05-$ no statistical significant

Surprisingly, we did not observe any statistical significance comparing serum concentration of SDF- $1 \alpha$ in the SSc and healthy control groups. This may suggest that either the homeostasis between SDF- $1 \alpha$ and CXCR4 is maintained or the hypothetical decreased level of CXCR4 [22, 23] does not influence the increased level of SDF-1 $\alpha$ in the serum in our patients. In our studies we observed a tendency for a negative Spearman's correlation coefficient, which might indicate that investigation of a larger group of patients could be positive and it also means that the level of SDF-1 $\alpha$ would decrease with the course of the disease. Interestingly, cell recruitment from bone marrow might even be within normal limits. Furthermore, Cipriani reported a significantly lower expression of CXCR4 in SSc mesenchymal stem cells, thus lowering their differentiation into endothelial cells. Underexpression of CXCR4 may correlate with the duration of SSc by contrast with overexpression, which supports tumour growth and would stimulate excessive angiogenesis [24]. Moreover, Cipriani observed SDF-1 $\alpha$ and CXCR4 up-regulation in the skin of patients with early SSc, dSSc and ISSc, and also progressive reduction of these molecules with the course of the disease, which our study also suggests. The difference between our observations, where the level of SDF-1 $\alpha$ in SSc patient serum is the same as in the control subjects, and the observations described in the literature on up-regulation of SDF-1 $\alpha$ in the skin of SSc patients, may indicate only local impairment of the SDF-1 $\alpha / C X C R 4$ axis [25].

To summarize, a high level of pro-angiogenic factors may indicate disturbances in revascularization homeostasis. Patients with SSc show increased serum concentration of many proangiogenic factors including angiogenin, as was shown for the first time in our study, to hypothetically reconstruct blood vessels and increase tissue blood perfusion stimulated by hypoxia. 


\section{Acknowledgment}

This study was supported by personal grant Nr. 502-18-836 and grant of Medical University in Lodz Nr. 503-1152-2.

\section{References}

1. Lee SH, Wolf PL, Escudero R, Deutsch R, Jamieson SW, Thistletwaite PA. Early expression of angiogenesis factors in acute myocardial ischemia and infarction. N Engl I Med 2000; 342: 626-33.

2. Kuwana M, Okazaki Y, Yasuoka H, Kawakami Y, Ikeda Y. Defective vasculogenesis in systemi sclerosis. Lancet 2004; 364: 603-10.

3. Jo DY, Rafii S, Hamada T, Moore MA. Chemotaxis of primitive hematopoietic cells in response to stroma cellderived factor-1. J Clin Invest 2000; 105: 101-11.

4. Aghi M, Cohen KS, Klein RJ, Scadden DT, Chiocca EA. Tumor stromal-derived factor-1 recruits vascular progenitors to mitotic neovasculature, where microenvironment influences their differentiated phenotypes. Cancer Res 2006; 66: 9054-64.

5. Pablos JL, Amara A, Bouloc A, et al. Stromal-cell derived factor is expressed by dendritic cells and endothelium in human skin. Am J Pathol 1999; 155: 1577-86.

6. Cipriani P, Franca Milia A, Liakouli V, et al. Differential expression of stromal cell-derived factor 1 and its receptor CXCR4 in the skin and endothelial cells of systemic sclerosis patients: Pathogenetic implication. Arthritis Rheum 2006; 54: 3022-33.

7. Hu G, Riordan JF, Vallee L. Angiogenin promotes invasiveness of cultured endothelial cells by stimulation of cell-associated proteolytic activities. Proc Natl Acad Sci USA 1994; 91: 12096-100.

8. Hu GF, Strydom DJ, Fett JW, Riordan JF, Vallee BL. Actin is a binding protein for angiogenin. Proc Natl Acad Sci USA 1993; 90: 1217-21.

9. Soncin F. Angiogenin supports endothelial and fibroblast cell adhesion. Proc Natl Acad Sci USA 1992; 89: 2232-6.

10. Subcomittee for Scleroderma Criteria of American Rheumatism Association Diagnostic and Therapeutic Criteria Committee: preliminary criteria for the classification of systemic sclerosis (scleroderma). Arthritis Rheum 1980; 23: 581-90

11. Medsger TA Jr, Bomardieri S, Czirjak L, Scorza R, Della Rossa A, Bencivelli W. Assesment of disease severity and prognosis. Clin Exp Rheumatolo 2003; 21 (3 Suppl. 29): S42-6.

12. Kahaleh MB, Suttany GL, Smith EA, Huffstutter JE, Loadholt CB, LeRoy EC. A modified scleroderma skin score method. Clin Exp Rheumatol 1986; 4: 367-9.

13. Alivernini S, De Santis M, Tolusso B, et al. Skin ulcers in systemic sclerosis: determinants of presence and predictive factors of healing. I Am Acad Dermatol 2009; 60: 426-35.

14. Avouac J, Wipff J, Goldman O, et al. Angiogenesis in systemic sclerosis: impaired expression of vascular endothelial growth factor receptor 1 in endothelial progenitor-derived cells under hypoxic conditions. Arthritis Rheum 2008; 58: 3550-61.

15. Cipriani P, Guiducci S, Miniati I, et al. Impairment of endothelial cell differentation from bone marrow - derived mesenchymal stem cells. Arthritis Rheum 2007; 56: 1994-2004.
16. Shimoyama S, Kaminishi M. Angiogenin in sera as an independent prognostic factor in gastric cancer. J Cancer Res Clin Oncol 2003; 129: 239-44.

17. Patel JV, Sosin M, Gunarathne A, et al. Elevated angiogenin levels in chronic heart failure. Ann Med 2008; 40: 474-9.

18. Tello-Montoliu A, Marín F, Patel J, et al. Plasma angiogenin levels in acute coronary syndromes: implications of prognosis. Eur Heart 2007; 28: 3006-11.

19. McHugh NJ, Distler O, Giacomelli R, Riemekasten G. Non organ based laboratory markers in systemic sclerosis. Clin Exp Rheumatol 2003; 21 (3 Suppl 29): S32-8.

20. Scheja A, Akesson A, Geborek P, et al. Von Willebrand factor propeptide as a marker of disease activity in systemic sclerosis (scleroderma). Arthritis Res 2001; 3: 178-82.

21. Kortesidis A, Zannettino A, Isenmann S, Shi S, Lapidot T, Gronthos S. Stromal-derived factor-1 promotes the growth, survival and development of human bone marrow stromal stem cells. Blood 2005; 105: 2643-5.

22. Cipriani P, Franca Milia A, Liakouli V, et al Differential expression of stromal cell-derived factor 1 and its receptor CXCR4 in the skin and endothelial cells of systemic sclerosis patients: Pathogenetic implications. Arthritis Rheum 2006; 54: 3022-33.

23. Campioni D, Lo Monaco A, Lanza F, et al. CXCR4 pos circulating progenitor cells coexpressing monocytic and endothelial markers correlating with fibrotic clinical features are present in the peripheral blood of patients affected by systemic sclerosis. Haematologica 2008; 93 : 1233-7.

24. Askari AT, Unzek S, Popovic ZB, et al. Effect of stromalcell-derived factor 1 on stem cell homing and tissue regeneration in ischaemic cardiomyopathy. Lancet 2003; 362: 697-703.

25. Manetti M, Liakouli V, Fatini C, et al. Association between a stromal cell-derived factor 1 (SDF-1/CXCL12) gene polymorphism and microvascular disease in systemic sclerosis. Ann Rheum Dis 2009; 68: 408-11. 